tera, Hexacladium and Articulospora. In Curucispora ponapensis Matsushima (1981), the branches form a pleurogenous dichotomy. In C. ombrogena Ando \& Tubaki (1984) there is also a dichotomy, although it is at the apex of the main axis, followed by the appearance of a further branch laterally on the first element. In Isthmotricladia Matsushima (1971) the conidial branches are clearly apical and arranged coronately. Enantioptera Descals (Descals \& Webster, 1983) and Hexacladium Olivier (1983) typically have two pairs of lateral branches, but these are also pleurogenous. Hexacladium, moreover, occurs on pollen. Articulospora ozeensis Matsushima (1975) has much smaller conidia with a short axis and one apical and two subacrogenous branches. Finally, the clampless supposed monokaryon of Taeniospora descalsii Marvanová \& Stalpers (1987), isolated from a Canadian stream by Marvanová \& Baerlocher (in press) has cruciate, considerably smaller, uniseptate conidia with mostly subopposite sequential branches.

We wish to thank Dr L. Marvanová (CCM) for kindly correcting this manuscript.

\section{REFERENCES}

ANDO, K. \& TUBAKI, K. (1984). Some undescribed hyphomycetes in the rain drops from intact leaf surface. Transactions of the Mycological Society of Japan 25, 21-37.

DESCALS, E. \& WEBSTER, J. (1983). Four new staurosporous hyphomycetes from mountain streams. Transactions of the British Mycological Society 80, 67-75.

DYKO, B. J. (1978). New aquatic and waterborne hyphomycetes from the Southern Appalachian mountains in the United States. Transactions of the British Mycological Society 70, 409-416.

MARVANOVÁ, L. (1986). Three new hyphomycetes from foam. Transactions of the British Mycological Society 87, 617-625.

MARVANOVÁ, L. \& STALPERS, J. A. (1987). The genus Taeniospora and its teleomorphs. Transactions of the British Mycological Society 89, 489-498.

MARVANOVÁ, L. \& BÄRLOCHER, F. (1989). Hyphomycetes from Canadian streams. I. Basidiomycetous anamorphs. Mycotaxon (In the press).

MATSUSHIMA, T. (1971). Some interesting Fungi Imperfecti. In Mycological Reports from New Guinea and the Solomon Islands 7 (ed. Y. Kobayasi). Bulletin of the National Science Museum, Tokyo 14, 460-480.

MATSUSHIMA, T. (1975). Icones Microfungorum a Matsushima lectorum. Kobe, Japan: published by the author.

MATSUSHIMA, T. (1981). Matsushima Mycological Memoirs 2. Kobe, Japan: published by the author.

NILSSON, S. (1964). Studies on freshwater hyphomycetes. Acta Universitatis Upsaliensis 37, 3-13.

OLIVIER, D. L. (1983). Phyllosphere fungi which capture wind-borne pollen grains. II. Hexacladium corynephorum gen. et sp. nov. Transactions of the British Mycological Society 80, 237-245.

\title{
Two new species of Dictyosporium from Taiwan
}

\author{
S. S. TZEAN AND J. L. CHEN \\ Department of Plant Pathology and Entomology, National Taiwan University, Taipei, Taiwan, R.O.C. 10746
}

Two new species of Dictyosporium from Taiwan. Mycological Research 92 (4): 497-502 (1989).

Dictyosporium bulbosum sp. nov. and D. verrucosum sp. nov. are described, illustrated and compared with other Dictyosporium species of similar conidial morpholgy.

Key words: Dictyosporium bulbosum, Dictyosporium verrucosum, New species, Cheiroid conidia.

Dictyosporium was erected by Corda in 1836 to accommodate a single species, D. elegans, which is characterized by cheiroid conidia (Ellis, 1971). Damon (1952) studied and compared the types in Dictyosporium, Speira and Cattanea, and provided a key to Dictyosporium, including seven accepted species. Sutton (1985) published a note with brief discussion on some deuteromycete genera with cheiroid or digitate brown conidia. Dictyosporium australiense was erected as a new species, and D. subramanianii sp. nov. was proposed for the invalidly published D. intermedium Subram, and D. circinatum Cke \& Harkn. was transferred to Helicorhoidion. An additional new species, D. gauntii Bhat \& Sutton (1985), was described, and brought the total in Dictyosporium to 21 (Batista et al., 1960;
Batista \& Farr, 1960; Ellis, 1971; Gareth Jones, 1963; Kirk \& Spooner, 1983; Saccardo, 1918; Matsushima, 1975, 1980, 1981; Subramanian, 1971; Van Emden, 1975).

In surveying Hyphomycetes from Taiwan, many new or interesting species have been recovered from fallen, decaying stems or leaves, and two of them are congeneric with Dictyosporium, but with morphological characteristics which differ from any documented species.

\section{Dictyosporium verrucosum Tzean \& Chen, sp. nov.}

(Figs 1-6)

Coloniae punctiformes, dispersae, pulveraceae oleae ad oleas brunneas reversae in pallidis luteis ad obscure oleas umbras. Mycelium (2-5.2 
Fig. 1. Dictyosporium verrucosum, conidiophores, conidiogenous cells and conidia.

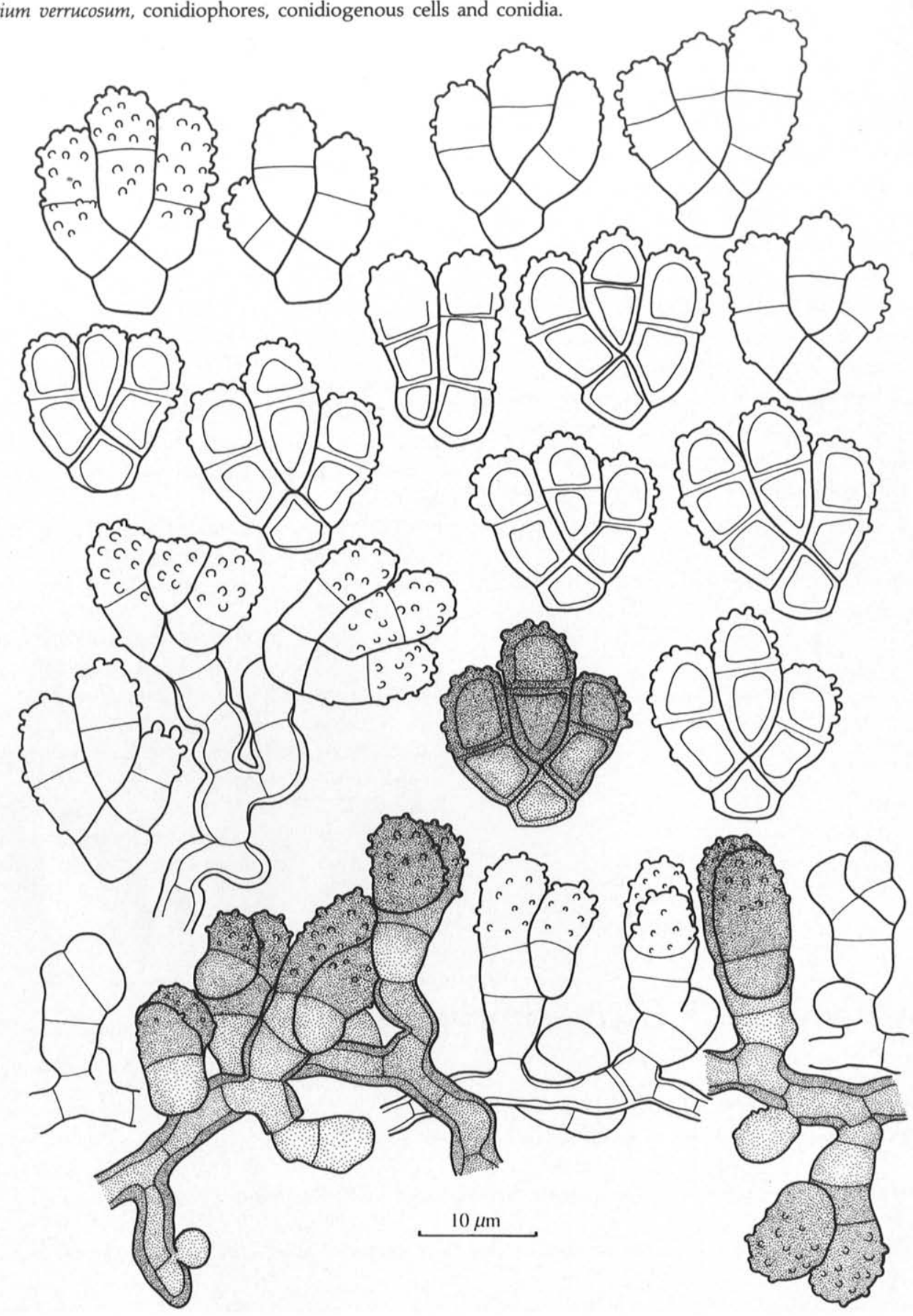

$\mu \mathrm{m})$ maximam partem immersum, ramosum, septatum, subinde turma 3-5 anastomosis, faciens funiculus structura, subhyalinum. Conidiophorum portatum directe super mycelio, solitarium vel aggregatum ad caespitosum, faciens sporodochium, hyalinum ad pallidum brunneum, laeve, crasso-paries, usque ad $1 \cdot 7 \mu \mathrm{m}$, micro-, semi-, macronematoideum, mononematoideum, flexuosum, simplex vel irregulariter ramosum, 4-12 $\times 2 \cdot 4-5 \mu \mathrm{m}$. Cellulae conidiogenae, in conidiophoris incorporatae vel discretae, acropleurogenae, cylindricae, doliiformes vel sphaeroideae, pallide brunneae ad brunneae, laeves, 3.5-13 $\times 3 \cdot 1-5 \cdot 8 \mu \mathrm{m}$. Conidia holoblastica, solitaria, exsiccata, acrogena vel pleurogena, pallide brunnea ad oleam brunneam, 14-22 $\times 10-18 \mu \mathrm{m}$, coalita cellulae basalis truncatae, $2 \cdot 8-5 \cdot 2 \mu \mathrm{m}$ lata quae 2-3 (maximam partem 3 ) verticalis, stricta vel leviter brachium curvum oriens, parallele adpressa simul et complanata in una plana. Brachia valde verrucosa $\frac{12}{2} 3$ apicis, 0-3 septata, 4.6-5.4 $\mu \mathrm{m}$ lata, constantia $6-9$ cellulae.
Holotypus in caulis emortuis, Tsubeu forestry recreation area, Taitung, Taiwan, 30 Mar. 1987, PPH1.

Colonies punctiform, scattered, powdery olive to olive brown, reverse in pale yellow to dull olive shade. Mycelium $(2-5 \cdot 2 \mu \mathrm{m})$ mostly immersed, branched, septate, occasionally groups of 3-5 anastomosed, forming a funicular structure, subhyaline. Conidiophores borne directly on the mycelium, solitary or aggregated to caespitose, forming sporodochia, hyaline to pale brown, smooth, thick-walled, up to $1.7 \mu \mathrm{m}$, micro-, semi-, macronematous, mononematous, flexuous, simple or irregularly branched, 4-12 $\times 2 \cdot 4-5 \mu \mathrm{m}$. Conidiogenous cells integrated or discrete, acropleurogenous, cylindrical, doliiform, or sphaeroid, pale brown to brown, smooth, $3.5-13 \times 3 \cdot 1-5.8 \mu \mathrm{m}$. Conidia holoblastic, solitary, dry, acro- 
Figs 2-6. Morphology of Dictyosporium verrucosum. Fig. 2. Conidia initiated from doliform conidiogenous cells. Fig. 3. Simple or branched conidiophores with conidia arising from hyphal bundles. Fig. 4. Crooked conidiogenous cells bearing an almost mature conidium and a newly initiated one. Fig. 5. Conidia with distinctive verrucose cells. Fig. 6. Composite of cheiroid conidia. Bars $=10 \mu \mathrm{m}$.

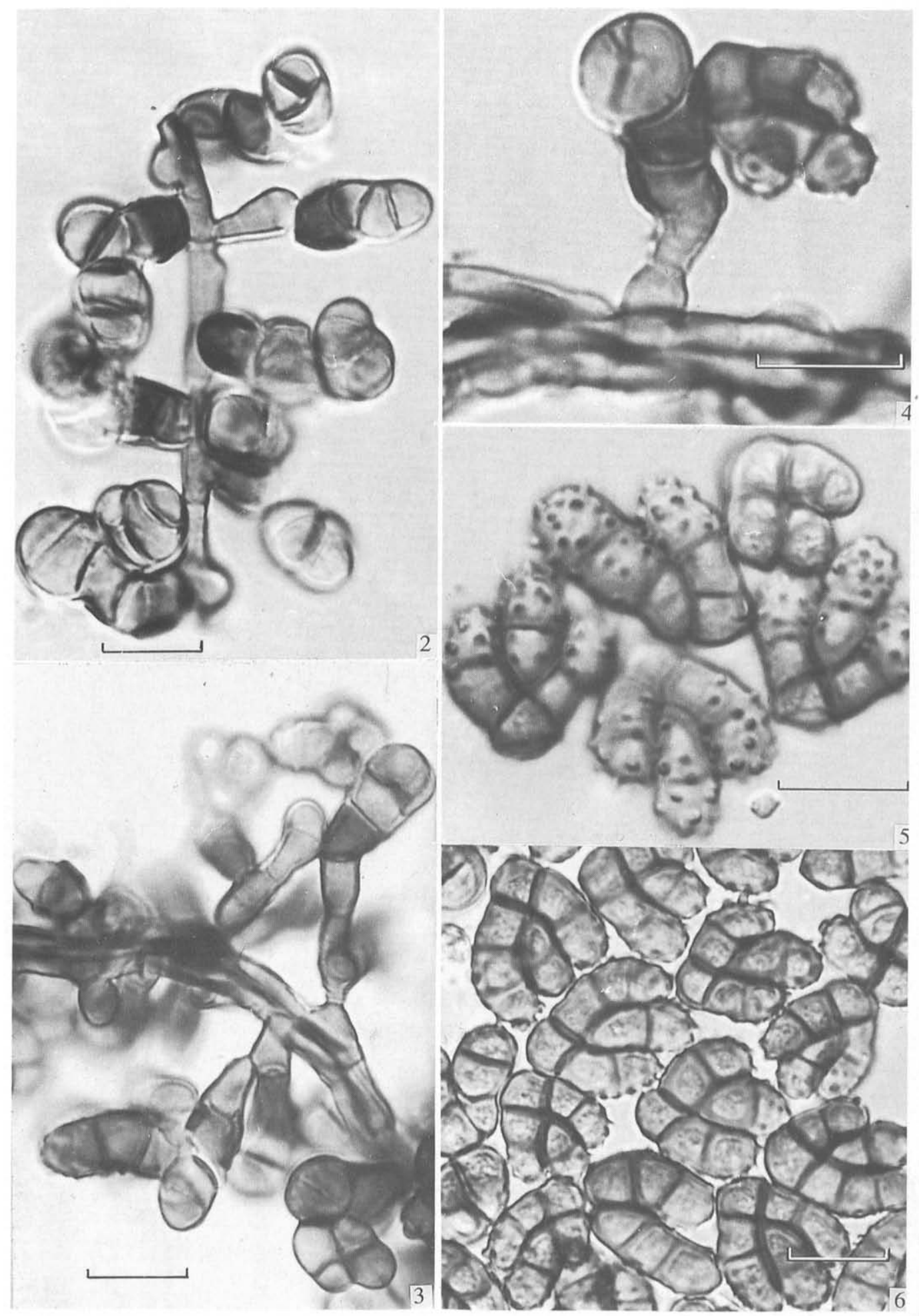

genous or pleurogenous, pale brown to olive brown, 14-22 $\times 10-18 \mu \mathrm{m}$, composed of a truncate basal cell, $2 \cdot 8-5 \cdot 2$ $\mu \mathrm{m}$ wide, on which $1-3$ (mostly 3 ) vertical, straight or slightly curved arms arise, parallel and appressed together, flattened in one plane. Arms markedly verrucose at $\frac{1}{2}-\frac{2}{3}$ of the apex, $0-3$ septate, $4 \cdot 6-5 \cdot 4 \mu \mathrm{m}$ wide, consisting of $6-9$ cells.
Specimens examined: on fallen stem, Tsubeu forestry recreation area, Taitung, Taiwan, 30 Mar. 1987. Holotype PPHI, iso-type PPHIE, deposited in Department of Plant Pathology and Entomology, National Taiwan University, Taipei, Taiwan, R.O.C., also deposited in Culture Collection and Research Center (CCRC). Hsinchu, Taiwan, R.O.C. 
Fig. 7. Dictyosporium bulbosum, conidiophores, conidiogenous cells and conidia.
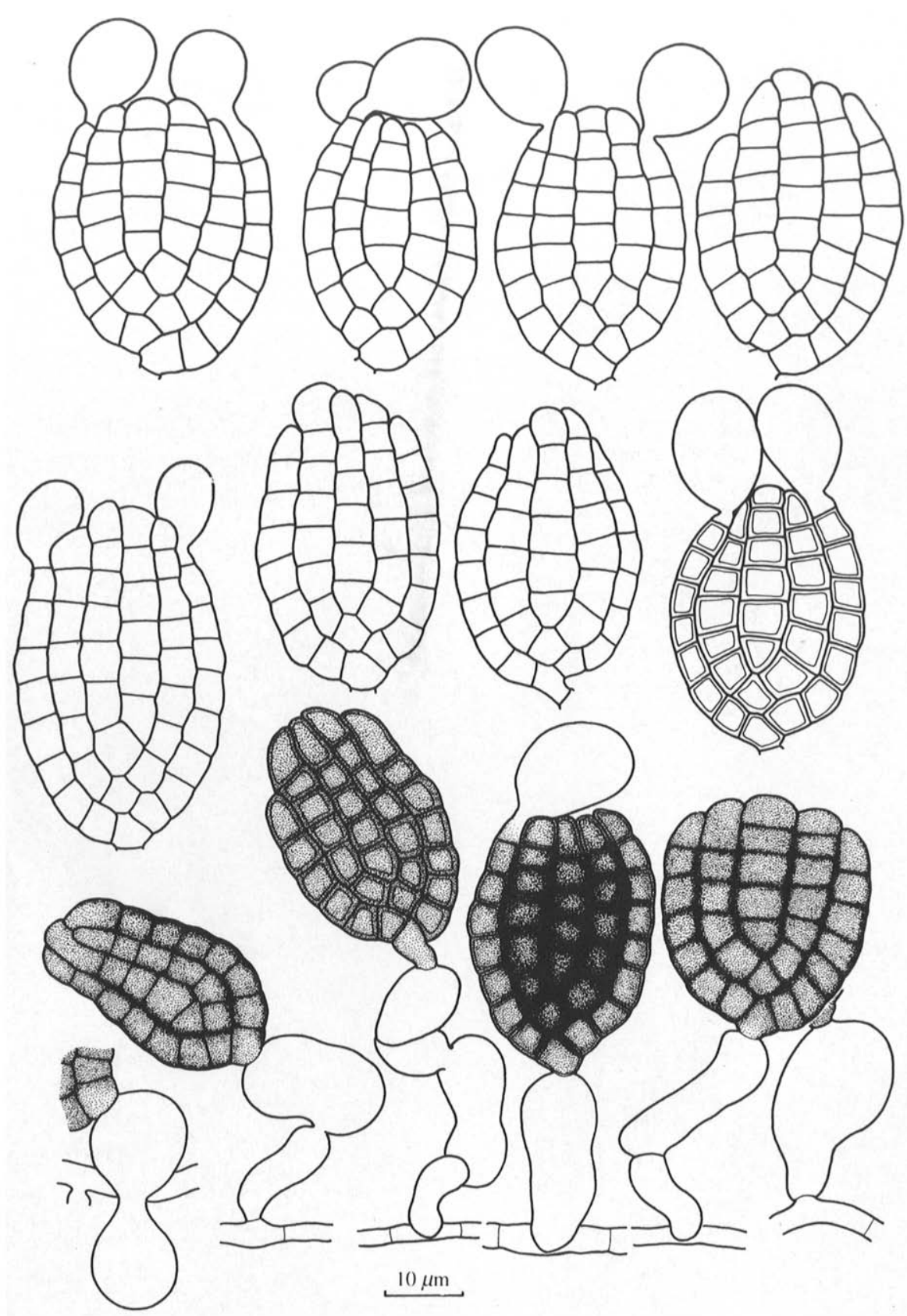

Dictyosporium bulbosum Tzean \& Chen, sp. nov.

(Figs 7-11)

Coloniae effusae, zonatae constantes punitatae ad pulveraceae sporodochia, sporodochium usque ad $c a 886 \mu \mathrm{m}$ diam, atroviridis. Mycelium maximam partem immersum, 2-6 $\mathrm{\mu m}$ latum, ramosum, septatum, incolor, subhyalinum ad dilutum viride. Conidiophorum micro- vel macronematoideum, mononematoideum, flexuosum, irregulariter ramosum, hyalinum, diluturn viride vel dilute brunneum, laeve. Cellulae conidiogenae in conidiophoris incorporatae, determinatae, terminales vel intercalares, cylindraceae, sigmoideae, reniformes, obovoideae, pyriformes, obpyriformes, subsphaericae vel sphaericae, hyalinae ad dilutae. Conidia 12-48 cellulae disposita in 2-6 serietibus, jecta in una plana, olea brunnea, $26 \cdot 9-46 \times 11 \cdot 1-30 \mu \mathrm{m}$. Cellula apicalis exteriorum serietum instructa hyalina, appendix parietis tenuis prime sphaerica, posteaescens obovoidea, $11-28 \times 10-19 \mu \mathrm{m}$ Appendex maximam partem 0 vel 2 ; subinde 1 vel 3 .

Holotypus in caulis emortius, Wulai, Taipei, Taiwan, 4 Mar. 1987, PPH2.

Colonies effuse, with zonation consisting of punctate to powdery sporodochia up to $c a 886 \mu \mathrm{m}$ diam, dark green. Mycelium mostly immersed, 2-6 um wide, branched, septate, colourless, subhyaline to pale green. Conidiophores micro- or macronematous, mononematous, flexuous, irregularly branched, hyaline, pale green or pale brown, smooth. Conidiogenous cells integrated, determinate, terminal or intercalary, cylindrical, sigmoid, reniform, obovoid, pyriform, 
Figs 8-11. Morphology of Dictyosporium bulbosum. Fig. 8. Conidium with one bulbous appendage. Fig. 9. Conidium with two bulbous appendages. Fig. 10. Conidium arising from sigmoid conidiogenous cells. Fig. 11. Conidium arising from an elliposidal conidiogenous cell. Bars $=10 \mu \mathrm{m}$.

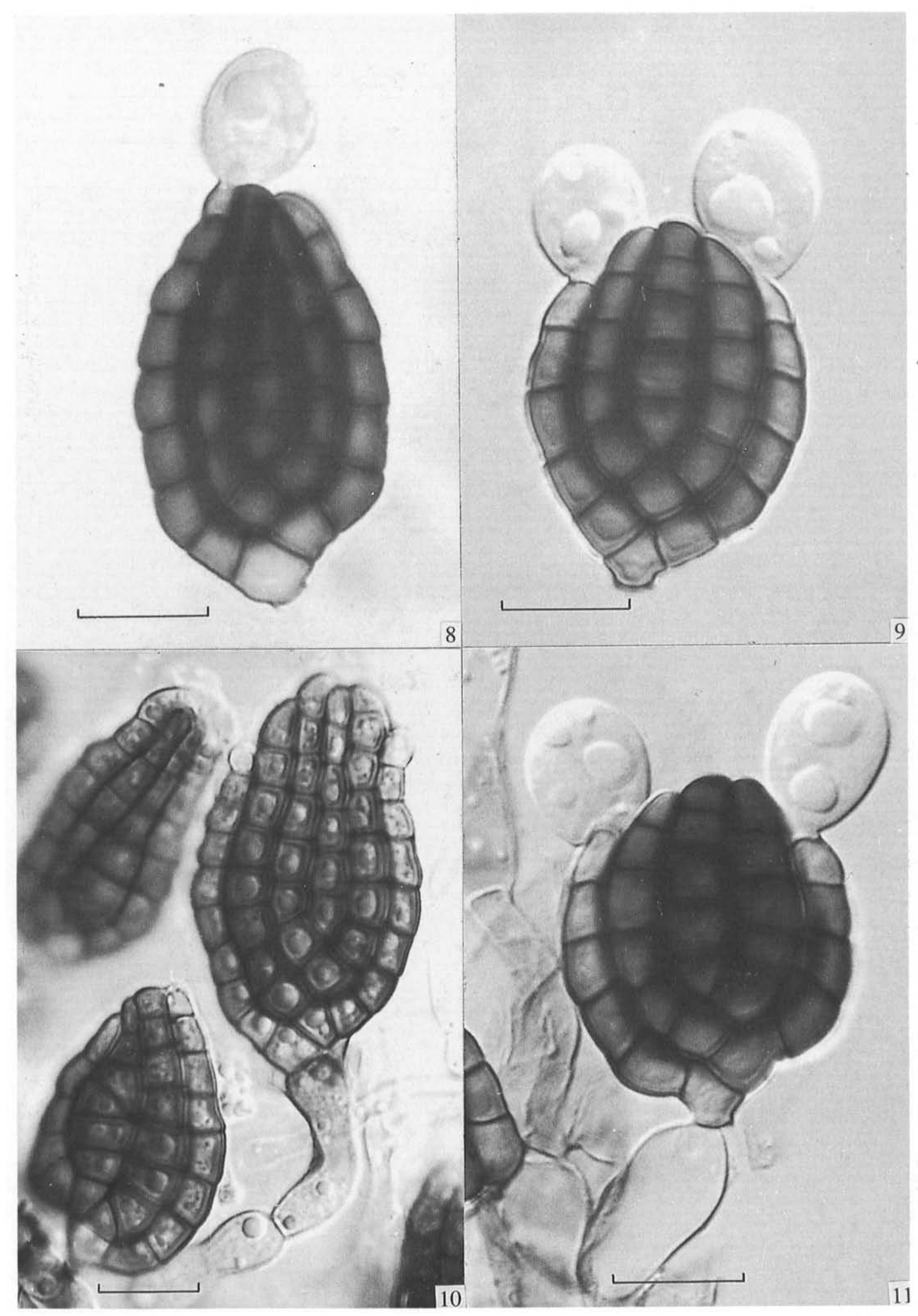

obpyriform, subspherical or spherical, hyaline to pale. Conidia of $12-48$ cells arranged in 2-6 rows, lying in one plane, olivaceous brown, $26 \cdot 9-46 \times 11 \cdot 1-30 \mu \mathrm{m}$. The apical cells of the outer rows provided with a hyaline, thin-walled appendage, initially spherical, later becoming obovoid, 11-28 $\times 10-19$ $\mu \mathrm{m}$. Appendages mostly 0 or 2 , occasionally 1 or 3 per conidium.

Specimens examined: on fallen, decayed stem, Wulai, Taipei, Taiwan, 4 Mar. 1987. Holotype $\mathrm{PPH} 2$, iso-type PPH2E, deposited in Department of Plant Pathology and Entomology, Taipei, Taiwan, 
R.O.C., also deposited in Culture Collection and Research Center (CCRC), Hsinchu, Taiwan, R.O.C.

Among the 21 accepted species in Dictyosporium, D. alatum Van Emden is the only species in which the apical cell of the outer rows of the conidia one ornamented with hyaline, thinwalled, allantoid appendages. Later, these become considerably swollen and contain crystalline material (Van Emden, 1975). Dictyosporum bulbosum is the second species with appendages, but they are mostly obovoid or bulbous, thin-walled and hyaline. The development of conidial appendages in $D$. alatum and $D$. bulbosum is similar but the final appearance is strikingly different. Conidiogenous cells and conidia in these two species also differ in shape and size.

Dictyosporium verrucosum is characterized by distinct features, such as conidia being composed of 3 short, stout, arms (rarely 2); cells of the arms are thick-walled, and conspicuously verrucose at the apex; the number of cells in each conidium is very low, consisting of only 6-9 (mostly 7), contrast to most other Dictyosporium species. All these features of $D$. verrucosum distinguish it from other described Dictysporium species.

The authors are grateful to $T$. Matsushima for his invaluable comments on taxa of currently described Dictyosporium species, and also thank Dr J. C. Liao for preparation of the Latin diagnosis. The research was supported by a grant NSC0409-B002-14 from the National Science Council, R.O.C., for which the authors are indebted.

\section{REFERENCES}

BATISTA, A. C., BEZERRA, J. L., DE SIQUEIRA, M. W. \& PERES, G. E. P. (1960). Benekea n. gen. e outros fungos imperfeitos. Universidade do Recife, Instituto de Micologia Publicacão 299, 24-25.

BATISTA, A.C. \& FARR, M. L. (1960). Algumas espécies de Dictyosporium e Podosporium (1). Universidade do Recife, Instituto de Micologia Publicacão 199, 103-104.

BHAT, D. J. \& SUTTON, B.C. (1985). New and interesting Hyphomycetes from Ethiopia. Transactions of the British Mycological Society 85, 107-122.

DAMON, S. C. (1952). Type studies in Dictyosporium, Speira, and Cattanea. Lloydia 15, 110-124.

ELLIS, M. B. (1971). Dematiaceous Hyphomycetes. Kew, England: CAB International Mycological Institute.

GARETH JONES, E. B. (1963). Marine fungi. II. Ascomycetes and Deuteromycetes from submerged wood and drift spartina Transactions of the British Mycological Society 46, 135-144.

KIRK, P. M. \& SPOONER, B. M. (1983). An account of the fungi of Arran, Gigha and Kintyre. Kew Bulletin 38, 503-597.

MATSUSHIMA, T. (1975). Icones Microfungorum a Matsushima Lectorum. Kobe, Japan: published by the author.

MATSUSHIMA, T. (1980). Saprophytic Microfungi from Taiwan. Part I. Hyphomycetes. Matsushima Mycological Memoirs 1, 1-82.

MATSUSHIMA，T. (1981). Matsushima Mycological Memoirs 2, $1-68$.

SACCARDO, P. A. (1918). Notae Mycologicae I. Fungi Singaporensis Bakgiana II. Fungi Abellinensis Novi. Bollettino dell'Orto botanico Napoli 6, 72 .

SUTTON, B. C. (1985). Notes on some deuteromycete genera with cheiroid or digitate brown conidia. Proceedings of the Indian Academy of Sciences (Plant Science) 94, 229-244.

SUBRAMANIAN, C. V. (1971). Hyphomycetes. New Delhi, India: Indian Council of Agricultural Research.

VAN EMDEN, J. H. (1975). Three new fungi from Surinam soil. Acta Botanica Neerlandica 24, 193-197.

\title{
Gilmaniella multiporosa, a new dematiaceous hyphomycete from Egyptian soils
}

\author{
A. F. MOUSTAFA AND E. K. EZZ-ELDIN \\ Department of Botany, Faculty of Science, Suez Canal University, Ismailia, Egypt \\ Gilmaniella multiporosa, a new dematiaceous hyphomycete from Egyptian soils. Mycological Research 92 (4): $502-505$ (1989). \\ Gilmaniella multiporosa, a new species of dark-coloured hyphomycetes, isolated from salt marsh soil in Egypt, is illustrated and \\ described. It produces conidia with 2-3 conspicuous germ pores.
}

Key words: Gilmaniella multiporosa, Soil fungi, Halophytes, New species.

During an ecological study of the fungal flora inhabiting the salt marsh ecosystem in North Sinai, Egypt, an interesting species of Gilmaniella was recorded several times. The most distinctive feature of this isolate is the production of conidia with numerous germ pores, a character which has not been reported previously for the genus. It is formally described as a new species and compared with four species already known. A key to accepted species is provided.
Gilmaniella multiporosa Moustafa \& Ezz-Eldin, sp. nov.

(Figs 1-3)

Coloniae in agaro PDA dict. $2 \hat{8}$ celeriter crescunt, post 7 dies ad $7 \mathrm{~cm}$ diam, laxe intricatae, velutinae, $2-3 \mathrm{~mm}$ altae, primum albae, cinerascens-olivaceiformes, margine angusta alba circumdatae. Hyphae ariae hyalinae, deinde dilute pigmentatae laeves, septis crassis, obscuris divisae. Cellulae conidiogenae laterales orthotropicae vel intercalares e cellulis haud differentiatis oriuntur, hyalinae, deinde 